\title{
Effects of Sales Promotion on Consummer Buying Behavior of Food Seasoning Among Nigerian House Holds: A Case Study of Nestle Maggi Naijapot'
}

\author{
Marcus Garvey Orji ${ }^{1}$, Michael Oyenuga ${ }^{2}$, Agnes Iember Ahungwa ${ }^{3}$ \\ ${ }^{1}$ Department of Business Administration, Veritas University, Abuja, Nigeria \\ ${ }^{2}$ Department of Business Administration, Veritas University, Abuja, Nigeria \\ ${ }^{3}$ Department of Business Administration, Veritas University, Abuja, Nigeria \\ marcusorji@gmail.com
}

\begin{abstract}
The major concern to Nigerian companies has been how do promote made in Nigeria food products like food seasoning that has been produced in line with our local taste and culture. It is in this context that this study seeks to examine the effects of sales promotion on the consumer buying behavior of food seasoning among Nigerian households using Nestle Nigeria Plc Maggi NAIJA POT brand as a case study. The study employed cross sectional research design and the population consists of consumers of Nestle product (Maggi seasoning) in Bwari Area Council, Abuja. The sample size is 246 determined using Topman's formula. Primary data was used through administration of questionnaire and regression analysis was used to test the relationship between the study variables. The findings revealed that most of the consumers enjoy the rebates which influence their decision before, during and after the purchase; there is a positive effect of free trial and free gift on consumer buying behavior of Maggi NAIJAPOT in Bwari Area Council, Abuja. The study concluded that that sales promotion through rebates, free trial and free gifts is one significant tool marketing companies should give attention to in order to influence their consumers' buying behavior, and recommended among others that providing free samples for food seasoning is a good technique to use in introducing new products to the Nigerian marketplace, also free gift should be included in the outer part of the product packaging to serve as a visual attraction to Nigerian consumers. It may also take the form of the commonly used terminology BOGOF' (Buy one get one free)
\end{abstract}

Keywords

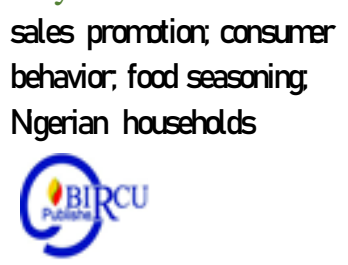

\section{Introduction}

Over the years, companies based their whole effort on just producing quality goods and services and forgot that the backbone and assurance for survival are the end users which are the final consumers. If marketing has one goal, it is to reach consumers at the moment that most influence their decision.

Attracting new customers has become very important in modern business in addition to loyalty, as the cost of maintaining consumers is less than the cost of attracting new customers. Firms therefore have to rethink the relationship between attitude and behavior of their consumers if they must be competitive and survive. According to Romdonny, Juju, Jusuf and Rosmadi (2018) to maintain customers, of course business people must be able to know the tastes of consumers, especially from the social psychological aspects and consumer 
culture which can change at any time. And all businesses need to communicate to the consumer what they have to offer, and in an attempt to communicate, promotion is necessary (Ahungwa 2018; Jobber \& Lancaster, 2006).

Promotion refers to the motivational methods of getting the consumer to purchase the product. Promotion is also refers to "any communication used to inform, persuade, and/or remind people about an organizations or individuals goods, services, image, ideas, community involvement, or impact on society" (Evans \& Berman, 1997). It mainly consists of messages and related media that are used to communicate with the market

The basics of sales promotion strategy involve delivering the communicational message(s) from the producer (or company) to the consumer. The object of the message is to persuade the audience to purchase the product or service. Therefore the consumer needs to be receptive to the message and to be able to interpret it in such a way that it influences him/her to purchase the product. Sales promotion is certainly one of the critical elements in marketing mix and tool kit for the marketers. Statistics for packaging companies show that sales promotion comprises nearly $75 \%$ of the marketing budget (Neslin, 2002).

According to Orji (2017), Consumer buying behavior is the study of individual, groups, organizations and all the activities associated with the purchase, use and disposal of goods and services, including the consumers emotional, mental and behavioral responses. The study of consumer behavior is concerned with all aspects of buying behavior - from pre-purchase activities through to post-purchase consumption, evaluation and disposal activities. It is also concerned with all persons involved, either directly or indirectly, in buying decisions and consumption activities including brand-influencers and opinion leaders. Company and marketers sought to grab consumers' attention through glitzy advertising campaigns and then "push" them through the funnel, maximizing conversions to avoid losing customers along the way. Companies that apply consumer behaviour while producing their products and services have a distinct competitive advantage that distances them from their rivals. Every business has a target audience and companies that look at consumers buying behavior tends to understand its end users and this is achieved through consumer behavior study and research. The organizations that have an intimate understanding of their target audience possess a competitive advantage over those that do not. Establishing a one-to-one relationship and thorough knowledge of your target audience is a core responsibility for business in the 21st century and beyond (Ahungwa, 2018).

For companies who fail to look at consumers as the King and their buying behavior will have no share in the competitive market and as such will be on its way to total decline thereby losing out in profits. These companies will also not be attractive for investors and will be left with no other option but to divest or harvest their product. The greater the satisfaction received by consumers and the higher the value of customer loyalty, the greater the profits the company will get (Romdonny \& Rosmadi, 2019). Research on sales promotion tools is important to understand the factors that affect a company's competition with its competitors, so that they can use the most effective techniques for promotion of their products and/or services and attract and maintain customers. Typical tools include free samples, price reduction and discounts, giving advertising gifts and offering coupons, membership cards, installment payments, extension of warranty period, and so on. It is in the light of this that this study seeks to assess the effect of sales promotion on the consumer buying behavior of food seasoning among Nigerian households with particular emphasis on Nestle Plc Maggi NAIJA POT Cubes brand. 


\subsection{Statement of the problem}

The basic belief of marketing-oriented company is that the customer is the hub around which the business revolves. Therefore, understanding what makes people in general buy and what makes customer in particular buy is a vital part of business success. This implies that in ever changing marketing environment, there is a growing concern or awareness among marketers to go for a careful study of the consumer buying behavior around which all marketing activities are made.

In Nigeria, consumer buying behavior towards made-in-Nigeria products has been a major challenge facing marketers for centuries. Specifically, a major problem that has bedeviled Nigeria in her effort to develop her industrial sector is the apparent preference by Nigerians for foreign made goods. The most immediate manifestation of this problem is smuggling in the face of various attempts by governments of Nigeria to curtail the indiscriminate importation of consumer goods. Some major attempts to check this negative consumer buying behavior against locally made goods include the ban on certain import and promotional appeals on radio and television (Daramola, Okafor \& Bello, 2014). In spite of these, the problem has largely remained unsolved and the consequence had been a decline in various local industries, with the most adversely affected being the textile and food industry. No amount of patriotic slogans about made in Nigeria goods had been able to correct this trait in Nigeria consumers. It has persisted to the extent that many retailers in Nigeria use the foreign tags or labels as a selling tool especially in justifying high product prices. This negative attitude towards home made products contribute to the economic development of advanced countries and relegate culture heritage of the country in various fields, to the extent that some Nigerians were importing packaged soup and cooked rice. The concern is that, how do we promote made in Nigeria food products like food seasoning that has been produced in line with our local taste and culture? It is in the context of this problem that this study seeks to examine the effect of sales promotion on the consumer buying behavior of food seasoning among Nigerian households using Nestle Nigeria Plc Maggi NAIJA POT brand as a case study.

And on the whole, the study will provide answer to the following pertinent questions;

a. Do rebates have an effect on consumer buying behavior of food seasoning among Nigerian households, especially Nestle Maggi NAIJA POT Cubes?

b. Does free trials have an effect on consumer buying behavior of food seasoning among Nigerian households, especially Nestle Maggi NAIJA POT Cubes?

c. Do free gifts have an effect on consumer buying behavior of Nestle Maggi NAIJA POT Cubes?

\subsection{Research hypotheses}

The following hypothetical assumptions have been postulated for validation in line with the study questions raised;

H01: There is no significant effect of rebates on consumer buying behavior of food seasoning among Nigerian households, especially Nestle Maggi NAIJA POT Cubes

H02: There is no significant effect of free trial on consumer buying behavior of Nestle Maggi NAIJA POT Cubes.

H03: There is no significant effect of free gifts on consumer buying behavior of Nestle Maggi NAIJA POT Cubes. 


\section{Review of Literature}

\subsection{Sales Promotion}

Sales promotion consists of techniques that are aimed at increasing sales in the short run, meaning that they are mostly used for a short period of time. It offers control, and the costs can be much lower than of advertising. The main characteristics of sales promotions are that they offer better value for money and they try to cause responses immediately.

According to Mendez (2012), and Orji, Akhaine, Ezinmuo \& Boman (2019), there are different ways to classify sales promotions; the most basic is to classify them between trade promotions and consumer promotions. Consumer promotion as defined by Joseph (2018) as a marketing technique that is used to entice customers to purchase a product. Such promotions usually last for a set period of time and are used to achieve a specific purpose, such as increasing market share or for unveiling a new product. Such consumer promotions tools include sampling, free trials, free gifts, contests, and special pricing.

Mendez (2012) also stated that consumer sales promotions take many forms, but are mainly classified as nonmonetary and monetary promotions. Monetary promotions refer to monetary incentives, such as coupons, rebates, and discounts, while nonmonetary promotions refer to samples, premiums, displays, sweepstakes, and contests

One of the most important reasons for a sales promotion is to elicit a direct impact on the purchase behavior of the firm's consumers. It is continuously said that most types of sales promotions affect the decision-making and buying stages of the buying process directly and is very effective in the long-run as it leads directly to increased sales, and hence profit (Kwok \& Uncles, 2005).

\section{a. Types of Sales Promotion}

Essentially, sales promotions are categorized into three depending on the initiator and the target of the promotion. These include: consumer promotion, Retailer promotions and trade promotions.

Consumer promotions; are those efforts aimed at influencing the trial consumer. They are promotions offered by manufacturers directly to consumers. Such promotions are designed to motivate consumers to immediate (or nearly immediate) action. Consumer's promotion techniques can be used to draw people into a particular store, to induce new product or to promote established products. According to Ahungwa (2018), to accomplish this task, marketers have developed quite a variety of sales promotion techniques or tools, sometimes

Consumers get benefits from attractive bonus packs and premium items with purchase as well as price discount.

Retailer promotions; are promotions offered by retailers to consumers. These include allowances and discounts, factory-sponsored in-store demonstration, trade shows, sales contests, cooperative advertising etc (Gilbert \& Jackaria 2002)

Trade promotions; are promotions offered by manufacturers to retailers or other trade entities. They are the aspect where the manufacturer is concerned not only with promoting the product to the consumers but also with whether the product is on the retailers' shelves when the customers go to the store to buy (Osuala, 1998). Retailer promotion and consumer promotion are directed toward the consumers by retailers and manufacturers, respectively. The manufacturers direct trade promotion to the retailers and the retailers direct to the consumers (Mahmud, Mohammed \& Sultan 2014). 


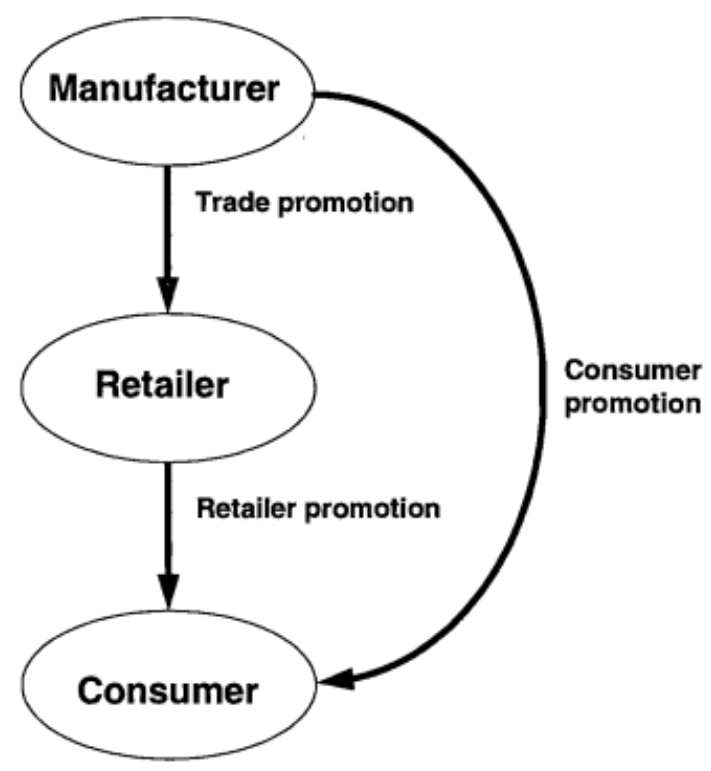

Figure 1. Illustrates types of sales promotion

Source: Per-Goran, P. (1995) in Ahungwa (2018)

\section{b. Sales promotion tools}

Sales promotions are temporary deals, events and ways of communicating with potential customers to motivate them to spend, or spend more. Adapting a variety of common sales promotions to marketing situation helps increase revenues and profits. According to Ahungwa (2018) there are four types of sales promotions tools which are: coupons, samples, rebates and Bonus packs. But our emphasis is on rebates, samples (free trials) and bonus (free gifts) which is suitable to our case sudy-Nestle Maggi NAIJA POT'.

1. Samples

Free Samples and Premiums are also among the most important tools of sales promotion. Free samples are trial amount of a certain product distributed to customers through so many different ways like handing them in front of office buildings, send them by mail or attach the sample to another different product. Free samples stimulate the trial of a new product during the introduction stage of the product (Ahungwa, 2018). However, the problem of samples is that it is the most expensive sales promotion tool. Providing free samples is a technique used to introduce new products to the marketplace. Samples give the consumer a chance to see how well they like a product or try something they otherwise would not normally buy, like Maggi NAIJA POT'

2. Rebates

Rebates are also a form of sales promotion that could be likened to coupons. Nonetheless, there exists a major distinction between both of them: the coupons amounts are redeemed during purchase but rebates are redeemed after purchase. This ambiguity could be resolved by explaining the process of the rebates: when a customer purchases a product - subject to rebate discount - he/she sends the proof of purchase like the receipt and the company sends him the money afterwards by mail (Kotler \& Armstrong 2010). This was always conceived as the main disadvantage of rebates as the uncertainty of redeeming the money persists after buying the product which constitutes the major dissimilarity between coupon and rebates (Lu \& Moorthy 2007). 
3. Bonus pack

Marketers also refer sometime to bonus pack as a mean to promote sales to their customers. Bonus pack could be exemplified where by a soft drink company may offer a 14 cans pack for the price of 12 cans making the customer benefit from 2 cans for free. The biggest deal in that field is the BOGO (Buy One, Get Other for free), as commonly used in Nigeria. Bonus packs could have several advantages as boosting sales in the short run without the need to reduce price (Ahungwa, 2018).

\subsection{Consumer and Consumer Behaviour}

According to Orji, Bello, Muktar \& Usman (2017) Consumer is the one who ultimately utilizes the goods and services produced, while customer is a person, company or other entity which patronizes another person, company, or other entity regularly. A consumer may be a customer, while a customer may not be a consumer, because he/she may not be buying for his or her uses.

But in studying consumer behavior, customers are also generally referred to as consumers, because whether they are the buyers or users, there is an exchange or transfer from one person to another for needs satisfaction. Thus, consumer behaviour is the study of the processes involved when individuals or groups select, purchase, use or dispose of products, services, ideas or experiences to satisfy needs and desires.

Buying behaviour is the decision processes and acts of people involved in buying and using products, where as, consumer buying behaviour refers to the buying behaviour of the ultimate consumer (Orji et al, 2017). Also, according to Orji et al (2017), consumer buying behavior involves purchasing and other consumption related activities of people engaging in the exchange process. It has also been described as the mental, emotional and physical activities that people engage in when selecting, purchasing, using and disposing of products and services so as to satisfy needs and desires.

Behavior of consumer is motivated or purposive. The behavior is directed towards the goal of obtaining products or other resources. It is the activities of people engaged in actual and potential use of market items-whether products, services, retail environments or ideas. The better the firm understands its consumers like the Nigerian households, the more likely it becomes successful in the marketplace. Knowledge of consumer behavior would render immense help for planning and implementing marketing strategies in a competitive environment like Nigeria (Orji et al, 2017).

\subsection{Nestle Nigeria Plc Maggi NAIJA POT}

Nestle Nigeria Plc on Tuesday 7th November 2017 at it's flowergate factory Shagamu, Ogun state launched another addition to the family, a new seasoning cube called "MAGGI NAIJA POT". Mauricio Alarcon, MD/CEO of Nestle Nigeria in his opening remarks during the launching said, "We dedicate ourselves to deeply understanding the needs and preferences of our consumers, and then we tailor our products to suit local tastes and food cultures." The new seasoning cube developed in Nigeria based on the strong understanding of local cuisine, is a combination of natural smoked fish, stock fish and crayfish to give soups and pottages that bottom-pot taste that Nigerians love.

MAGGI NAIJA POT was developed with the aim of using more familiar and common ingredients, improve the nutritional profile of Maggi, increase local sourcing and build local economies and also raise awareness about healthy lifestyles, cooking and diets. The seasoning will help to save time, money and effort since Naija pot combines selected locally 
known ingredients in one small cube. It is also a source of iodine for higher nutritional value (www.pmnewsnigeria.com/2017/11/07)

It is these unique attributes of Maggi NAIJAPOT that motivated this study to focus on it for research.

\subsection{Theoretical Framework}

The theoretical framework upon which the study was based is Reasoned action theory and Engel, Kollet, Blackwell (EKB) model. Reasoned Action theory was propounded by Martin Fishbein and Icek Ajzen in the late 1960s, the Theory of Reasoned Action centers its analysis on the importance of pre-existing attitudes in the decision-making process. The core of the theory posits that consumers act on a behavior based on their intention to create or receive a particular outcome. In this analysis, consumers are rational actors who choose to act in their best interests. According to the theory, specificity is critical in the decision-making process. A consumer only takes a specific action when there is an equally specific result expected. From the time the consumer decides to act to the time the action is completed, the consumer retains the ability to change his or her mind and decide on a different course of action.

Sales personnel's learn several lessons from the Theory of Reasoned Action. First, when marketing a product to consumers, personnel's must associate a purchase with a positive result, and that result must be specific. Axe Body Spray used this concept very effectively by linking its product to desirability with women. Second, the theory highlights the importance of moving consumers through the sales pipeline. Sales personnel must understand that long lags between initial intention and the completion of the action allow consumers plenty of choice or decision (Ahungwa, 2018).

The EKB Model (1968) expands on the Theory of Reasoned Action, and lays out a five step process that consumers use when making a purchase. The first step, input, is where consumers absorb most of the marketing materials they see on television, newspapers or online. Once the consumer collects the data, he or she moves into information processing, where the consumer compares the input to past experiences and expectations. Consumers move to the decision-making stage after a period of thought, choosing to make a purchase based on rational insight. Consumers are affected in the decision-making phase by process variables and external influences, including how the consumer envisions his or herself after making the purchase.

Under the EKB Model, marketers have two periods where their input is the most valuable. During the initial information stage, marketers must provide consumers with enough information about the product to drive the consumer to keep the company's products under consideration for purchase. Marketing becomes a factor again in the phase of external influences. Lifestyle brands are very good at instilling desire in the consumer to look or feel a certain way with the product, like comparing Maggi NAIJA POT to indigenous crayfish and Dawadawa, even if the brands product is not fundamentally different from the compered one.

The outcome of this blend of theories that constitute the fulcrum of our study is the establishment of the linkages between them and consumer buying behavior of food seasoning like Maggi NAIJA POT among household in Nigeria. 


\section{Research Method}

The design of the study is a cross sectional survey research. Surveys help in obtaining important information from a large representative portion of a population. The cross sectional survey design is appropriate for this study because it seeks to examine the effect of sales promotional activities on consumer behaiour of food seasoning at one point in time from a representative sample selected to describe the population of the study. The broad nature of the research problem prompted the use of cross sectional survey design and its ability to act as an efficient technique in producing data from the population sample.

\subsection{Population of the Study}

The population of this study includes consumers of Nestle product (Maggi NAIJA POT' seasoning) within Bwari Area Council, Abuja, Nigeria. There is no definite population of the study due to the open nature of the consumers of the product under study.

Sample size determination; sample is a smaller group of selected items, that is, the subset of a given universe. Sampling is the process of selecting a given amount of elements from a universe on which a study will be conducted. The sample size for the study is 246 . It was determined using Topman formula (as shown below). Systemic random sampling technique was adopted in selecting those respondents that participated in the study

Topman's formula $\quad \mathrm{n}=$

Where:

$\mathrm{n}=$ sample size

$\mathrm{Z}=$ degree of confidence

$\mathrm{P}=$ probability of positive response

$\mathrm{Q}=$ probability of negative response

$\mathrm{E}=$ Estimated error margin

(Source: Weires, 2006)

In Weires,( 2006) as stated in Ahungwa (2018), the above formula is referred to as "population proportion. If $\mathrm{p}$ is not estimated, its value can be used at a constant of 0.5 . In this case, a pilot study using 10 respondents was conducted using convenience sampling and the result was $80-20 \%$ probability of positive responses to negative responses. Using inferential judgment a probability of positive and negative response was selected as 0.8 and 0.2.

Therefore, given a constant $95 \%$ degree of confidence, $\mathrm{z}=1.96$ as traced from the $\mathrm{z}$ table. Margin of error is $5 \%$

Therefore,

$$
\begin{aligned}
& \mathrm{n}=1.962 *(0.8 * 0.2) / 0.052 \\
& \mathrm{n}=1.962 *(0.16) / 0.0025 \\
& \mathrm{n}=3.8416 * 64 \\
& \mathrm{n}=245.8624 \\
& \mathrm{n}=246
\end{aligned}
$$

\subsection{Data Collection}

Data was obtained from primary source using survey questionnaires adapted by the study. The instrument was suitable given the study's reported reliability index of .79, which is high. Close ended questions were used for the questionnaire to enable faster data compilation and to easily classify the responses of respondents. The questionnaire was designed using the 5-point likert scale format. 


\subsection{Data Analysis}

Data obtained from the questionnaires administered to the respondents were analyzed using both descriptive and inferential statistics. The descriptive statistics was the use of simple percentage and mean and inferential statistics using linear regression technique. The choice of regression is because it explains the effect and relationship between two or more variables of interest. It shows the predictive strength of the influence of the independent variable on the dependent variable as opined by Orji (2017). Analysis was carried out using SPSSv21 (Statistical Package for Social Sciences).

\subsection{Model Specification}

The regression model used for the data analysis is;

$\mathrm{Y}=\mathrm{a}+\beta 1 \mathrm{X} 1+\beta 2 \mathrm{X} 2+\beta 3 \mathrm{X} 3 \ldots+\mathrm{e}$

$\mathrm{Y}=$ consumer buying behavior

$\mathrm{a}=$ Intercept (value of $\mathrm{Y}$ when $\mathrm{xj}$ is Zero)

$\beta \mathrm{j}=$ Regression weight attached to the variation $\mathrm{j}(\mathrm{j}=1,2,3)$

$\mathrm{Xi}=$ Rebates

$\mathrm{X} 2=$ Free trials

$\mathrm{X} 3=$ Free gifts

$\mathrm{C}=$ Error term

\section{Discussion}

Table 1. Descriptive analysis of Questionnaire items

\begin{tabular}{|c|c|c|c|c|c|c|c|c|c|c|}
\hline & Answer Key & & 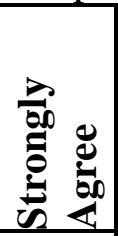 & 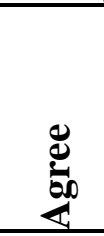 & 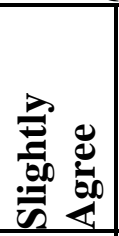 & 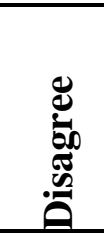 & 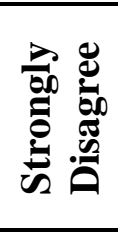 & 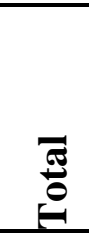 & 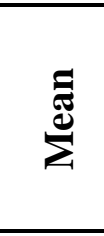 & 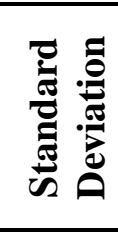 \\
\hline & Rebates & & & & & & & & & \\
\hline \multirow{2}{*}{1} & \multirow{2}{*}{$\begin{array}{l}\text { Maggi gives rebates } \\
\text { out to its customers }\end{array}$} & No & 8 & 13 & 36 & 39 & 121 & 216 & \multirow{2}{*}{3.17} & \multirow{2}{*}{1.124} \\
\hline & & $\%$ & 3.5 & 5.9 & 16.6 & 18.2 & 55.8 & 100 & & \\
\hline \multirow{2}{*}{2} & \multirow{2}{*}{$\begin{array}{l}\text { Rebates motivate } \\
\text { you to buy Maggi } \\
\text { seasoning? }\end{array}$} & No & 26 & 18 & 34 & 41 & 97 & 216 & \multirow{2}{*}{3.75} & \multirow{2}{*}{1.425} \\
\hline & & $\%$ & 12.0 & 8.2 & 15.7 & 19.1 & 45.0 & 100 & & \\
\hline \multirow{3}{*}{3} & \multirow{2}{*}{$\begin{array}{l}\text { You been given a } \\
\text { rebate before }\end{array}$} & No & 9 & 11 & 32 & 41 & 122 & 216 & \multirow{2}{*}{4.17} & \multirow{2}{*}{1.156} \\
\hline & & $\%$ & 4.1 & 5.3 & 14.9 & 19.1 & 56.6 & 100 & & \\
\hline & Free Trial & & & & & & & & & \\
\hline \multirow{2}{*}{1} & \multirow{2}{*}{ You like free trial } & No & 18 & 40 & 59 & 68 & 31 & 216 & \multirow{2}{*}{3.56} & \multirow{2}{*}{1.318} \\
\hline & & $\%$ & 8.4 & 18.4 & 27.3 & 31.4 & 14.5 & 100 & & \\
\hline \multirow{2}{*}{2} & \multirow{2}{*}{$\begin{array}{l}\text { You received Maggi } \\
\text { free gift before }\end{array}$} & No & 17 & 40 & 32 & 52 & 75 & 216 & \multirow{2}{*}{3.71} & \multirow{2}{*}{1.251} \\
\hline & & $\%$ & 7.7 & 18.4 & 14.9 & 24.2 & 34.8 & 100 & & \\
\hline 3 & You often receive & No & 26 & 30 & 28 & 71 & 61 & 216 & 3.70 & 1.205 \\
\hline
\end{tabular}




\begin{tabular}{|c|c|c|c|c|c|c|c|c|c|c|}
\hline & free gifts & $\%$ & 12.0 & 14.0 & 12.8 & 32.9 & 28.3 & 100 & & \\
\hline & Free Gifts & & & & & & & & & \\
\hline \multirow{2}{*}{1} & \multirow{2}{*}{$\begin{array}{l}\text { Do you like free } \\
\text { gift? }\end{array}$} & No & 34 & 50 & 28 & 84 & 19 & 216 & \multirow{2}{*}{3.59} & \multirow{2}{*}{1.106} \\
\hline & & $\%$ & 15.9 & 23.2 & 13.0 & 39.1 & 8.8 & 100 & & \\
\hline \multirow{2}{*}{2} & \multirow{2}{*}{$\begin{array}{l}\text { Have you received } \\
\text { Maggi free gift } \\
\text { before? }\end{array}$} & No & 13 & 49 & 25 & 66 & 64 & 216 & \multirow{2}{*}{3.31} & \multirow{2}{*}{1.207} \\
\hline & & $\%$ & 5.8 & 22.5 & 11.6 & 30.4 & 29.7 & 100 & & \\
\hline \multirow{3}{*}{3} & \multirow{2}{*}{$\begin{array}{l}\text { How often have you } \\
\text { been given free } \\
\text { gifts? }\end{array}$} & No & 11 & 28 & 16 & 88 & 74 & 216 & \multirow{2}{*}{3.24} & \multirow{2}{*}{1.321} \\
\hline & & $\%$ & 5.1 & 13.0 & 7.2 & 40.6 & 34.1 & 100 & & \\
\hline & $\begin{array}{l}\text { Consumer } \\
\text { purchasing } \\
\text { behavior }\end{array}$ & & & & & & & & & \\
\hline \multirow{2}{*}{1} & \multirow{2}{*}{$\begin{array}{l}\text { I purchase Maggi } \\
\text { seasoning } \\
\text { frequently }\end{array}$} & No & 16 & 23 & 30 & 80 & 67 & 216 & \multirow{2}{*}{3.71} & \multirow{2}{*}{1.251} \\
\hline & & $\%$ & 7.2 & 10.8 & 13.8 & 37.0 & $31.2 \%$ & 100 & & \\
\hline \multirow{2}{*}{2} & \multirow{2}{*}{$\begin{array}{l}\text { Changes in price } \\
\text { affect my purchase } \\
\text { of Maggi seasoning }\end{array}$} & No & 28 & 28 & 30 & 69 & 61 & 216 & \multirow{2}{*}{3.60} & \multirow{2}{*}{1.515} \\
\hline & & $\%$ & 13.0 & 13.0 & 13.8 & 31.9 & $28.3 \%$ & 100 & & \\
\hline \multirow[b]{2}{*}{3} & \multirow{2}{*}{$\begin{array}{l}\text { I buy Maggi } \\
\text { seasoning based on } \\
\text { my initial } \\
\text { perception of the } \\
\text { product. }\end{array}$} & No & 9 & 13 & 45 & 116 & 33 & 216 & \multirow[b]{2}{*}{3.19} & \multirow[b]{2}{*}{1.27} \\
\hline & & $\%$ & 4.3 & 5.8 & 21.0 & 53.6 & $15.2 \%$ & 100 & & \\
\hline
\end{tabular}

(Source; Field Survey; 2019)

Table 1 shows that the study sought to use "rebates" to examine whether it has effect on consumer buying behavior. The table shows that the highest ranked item was "Have you been given a rebate before?" $(\mathrm{M}=4.17 ; \mathrm{SD}=1.156)$, this was followed by "Do rebates motivate you to buy Maggi seasoning?" ( $\mathrm{M}=3.75 ; \mathrm{SD}=1.425)$.

Table 1 also shows that the study sought to use "Free Trial" to examine whether it has effect on consumer buying behavior. Based on the responses, the table shows that the highest ranked item was "Have you received free trial for Maggi seasoning before?" (M=3.71; $\mathrm{SD}=1.251)$, this was followed by "How often have you been given free trail?" $(\mathrm{M}=3.70$; $\mathrm{SD}=1.205)$.

Also the table shows that the study sought to use "Free Gifts" to examine whether it has effect on consumer buying behavior. Based on the responses, responses shows that the highest ranked item was "Do you like free gift?" $(\mathrm{M}=3.59 ; \mathrm{SD}=1.106)$, this was followed by "Have you received Maggi free gift before?" $(\mathrm{M}=3.31 ; \mathrm{SD}=1.207)$ and the lowest ranked is "How often have you been given free gifts?" $(\mathrm{M}=3.24$; $\mathrm{SD}=1.321)$.

Finally, the study sought to establish whether each of the dimensions of sales promotion used in this study (rebates, free trails and free gift) have effect on consumer buying behavior. The findings show that the highest ranked item was "I purchase Maggi seasoning frequently" $(\mathrm{M}=3.71 ; \mathrm{SD}=1.251)$ this was followed by "Changes in price affect my 
purchase of Maggi seasoning" $(\mathrm{M}=3.60 ; \mathrm{SD}=1.515)$ and the least ranked was "I buy Maggi seasoning based on my initial perception of the product" $(\mathrm{M}=3.19 ; \mathrm{SD}=1.270)$.

\subsection{Test of Hypothesis}

Hypothesis One: There is no significant effect of rebates on consumer buying behavior

Table 2. Model Summary for effect of rebates on consumer buying behaviour

\begin{tabular}{|l|r|r|r|r|}
\hline Model & \multicolumn{1}{|c|}{ R } & R Square & Adjusted R Square & \multicolumn{1}{|c|}{ Std. Error of the Estimate } \\
\hline 1 & $.644^{\mathrm{a}}$ & .518 & .614 & 3.16529 \\
\hline
\end{tabular}

a. Dependent Variable: Consumer buying behavior

b. Predictors: (Constant), Rebates

The study conducted a regression analysis to establish the direction of the relationship between the independent and dependent variable. Table 2 shows the model summary which shows that the $R^{2}$ is 0.518 which means that $51.8 \%$ of variation in consumer buying behavior is due to rebates as an aspect of sales promotion.

Table 3. ANOVA ${ }^{\text {a }}$ for effect of rebates on consumer buying behaviour

\begin{tabular}{|rl|r|r|r|r|r|}
\hline \multicolumn{1}{|l|}{ Model } & Sum of Squares & Df & Mean Square & F & \multicolumn{1}{c|}{ Sig. } \\
\hline \multirow{2}{*}{1} & Regression & 9.632 & 1 & 9.632 & 28.765 & $.000^{\mathrm{b}}$ \\
& Residual & 71.660 & 214 & .335 & & \\
& Total & 81.292 & 215 & & & \\
\hline
\end{tabular}

a. Dependent Variable: Consumer buying behavior

b. Predictors: (Constant), Rebates

Table 3 shows the ANOVA results of the linear regression analysis. The findings show that the significance level is $<0.005(p=0.000)$. This finding implies that the regression model is significant in explaining change in the study dependent variable.

Table 4. Coefficients ${ }^{\mathrm{a}}$ for effect of rebates on consumer buying behaviour

\begin{tabular}{|c|c|c|c|c|c|}
\hline \multirow[t]{2}{*}{ Model } & \multicolumn{2}{|c|}{$\begin{array}{l}\text { Unstandardized } \\
\text { Coefficients }\end{array}$} & $\begin{array}{l}\text { Standardized } \\
\text { Coefficients }\end{array}$ & $\mathrm{t}$ & Sig. \\
\hline & B & Std. Error & Beta & & \\
\hline (Constant) & 2.826 & .198 & & 14.257 & .000 \\
\hline Rebates & .281 & .052 & .644 & 5.363 & .000 \\
\hline
\end{tabular}

a. Dependent Variable: Consumer buying behavior

The regression coefficients show the size of the effect of the independent variables on the dependent variable. Table 4. shows that an increase in rebates leads to an increase in consumer buying behavior of Maggi NAIJA POT in Bwari Area Council, Abuja. The findings further revealed that rebates $(\beta=0.281, p<0.005)$ had effect on consumer buying behavior. The proposed regression model thus becomes: $\mathrm{Y}=2.826+0.281 \mathrm{X} 1+\varepsilon$ 

behavior

Hypothesis Two: There is no significant effect of free trial on consumer buying

Table 5. Model Summary for effect of free trial on consumer buying behavior

\begin{tabular}{|l|r|r|r|r|}
\hline Model & \multicolumn{1}{|c|}{ R } & R Square & Adjusted R Square & \multicolumn{1}{|c|}{ Std. Error of the Estimate } \\
\hline 1 & $.663^{2}$ & .569 & .564 & 2.59465 \\
\hline
\end{tabular}

a. Dependent Variable: Consumer buying behavior

b. Predictors: (Constant), Free trial

The study conducted a regression analysis to establish the direction of the relationship between the independent and dependent variable. Table 5 shows the model summary which shows that the $R^{2}$ is 0.569 which means that $56.9 \%$ of variation in consumer buying behavior is due to free trial as an aspect of sales promotion.

Table 6. ANOVA ${ }^{\text {a }}$ for effect of free trial on consumer buying behaviour

\begin{tabular}{|ll|r|r|r|r|r|}
\hline \multicolumn{1}{|l|}{ Model } & Sum of Squares & Df & Mean Square & F & \multicolumn{1}{c|}{ Sig. } \\
\hline \multirow{2}{*}{1} & Regression & 5.619 & 1 & 5.619 & 15.889 & $.000^{\mathrm{b}}$ \\
& Residual & 75.673 & 214 & .354 & & \\
& Total & 81.292 & 215 & & & \\
\hline
\end{tabular}

a. Dependent Variable: Consumer buying behavior

b. Predictors: (Constant), Free trial

Table 6 shows the ANOVA results of the linear regression analysis. The findings show that the significance level is $<0.005(p=0.000)$. This finding implies that the regression model is significant in explaining change in the study dependent variable.

Table 7. Coefficients ${ }^{\mathrm{a}}$ : effect of free trial on consumer buying behaviour

\begin{tabular}{|c|c|c|c|c|c|}
\hline \multirow[t]{2}{*}{ Model } & \multicolumn{2}{|c|}{$\begin{array}{c}\text { Unstandardized } \\
\text { Coefficients }\end{array}$} & $\begin{array}{l}\text { Standardized } \\
\text { Coefficients }\end{array}$ & $\mathrm{T}$ & Sig. \\
\hline & B & Std. Error & Beta & & \\
\hline (Constant) & 2.976 & .228 & & 13.073 & .000 \\
\hline Free trial & .258 & .065 & .663 & 3.986 & .000 \\
\hline
\end{tabular}

a. Dependent Variable: Consumer buying behavior

The regression coefficients show the size of the effect of the independent variables on the dependent variable. Table 7 shows that an increase in free trial leads to an increase in consumer buying behavior of Maggi NAIJA POT in Bwari Area Council, Abuja. The findings further revealed that free trial $(\beta=0.258, p<0.005)$ had effect on consumer buying behavior. The proposed regression model thus becomes: $\mathrm{Y}=2.976+0.258 \mathrm{X} 1+\varepsilon$

Hypothesis Three: There is no significant effect of free gifts on consumer buying behavior. 
Table 8. Model Summary for effect of free gifts on consumer buying behavior

\begin{tabular}{|l|r|r|r|r|}
\hline Model & \multicolumn{1}{|c|}{ R } & R Square & Adjusted R Square & \multicolumn{1}{|c|}{ Std. Error of the Estimate } \\
\hline 1 & $.588^{\mathrm{a}}$ & .446 & .443 & .49852 \\
\hline
\end{tabular}

a. Dependent Variable: Consumer buying behavior

b. Predictors: (Constant), Free gifts

The study conducted a regression analysis to establish the direction of the relationship between the independent and dependent variable. Table 8 shows the model summary which shows that the $R^{2}$ is 0.446 which means that $44.6 \%$ of variation in consumer buying behavior is due to free gifts as an aspect of sales promotion.

Table 9. ANOVA ${ }^{\text {a }}$ for effect of free gifts on consumer buying behaviour

\begin{tabular}{|c|c|c|c|c|c|}
\hline Model & Sum of Squares & Df & Mean Square & $\mathrm{F}$ & Sig. \\
\hline Regression & 28.107 & 1 & 28.107 & 113.096 & $.000^{\mathrm{b}}$ \\
\hline Residual & 53.185 & 214 & .249 & & \\
\hline Total & 81.292 & 215 & & & \\
\hline
\end{tabular}

a. Dependent Variable: Consumer buying behavior

b. Predictors: (Constant), Free gifts

Table 9 shows the ANOVA results of the linear regression analysis. The findings show that the significance level is $<0.005(p=0.000)$. This finding implies that the regression model is significant in explaining change in the study dependent variable

Table 10. Coefficients ${ }^{\mathrm{a}}$ : effect of free gifts on consumer buying behaviour

\begin{tabular}{|c|c|c|c|c|c|}
\hline \multirow[t]{2}{*}{ Model } & \multicolumn{2}{|c|}{$\begin{array}{c}\text { Unstandardized } \\
\text { Coefficients }\end{array}$} & $\begin{array}{l}\text { Standardized } \\
\text { Coefficients }\end{array}$ & \multirow[t]{2}{*}{$\mathrm{T}$} & \multirow[t]{2}{*}{ Sig. } \\
\hline & B & Std. Error & Beta & & \\
\hline (Constant) & 1.255 & .248 & & 5.061 & .000 \\
\hline Free gifts & .694 & .065 & .588 & 10.635 & .000 \\
\hline
\end{tabular}

a. Dependent Variable: Consumer buying behavior

The regression coefficients show the size of the effect of the independent variables on the dependent variable. Table 10 shows that an increase in free gifts leads to an increase in consumer buying behavior of Maggi NAIJA POT in Bwari Area Council, Abuja. The findings further revealed that free gifts $(\beta=0.694, p<0.005)$ had effect on consumer buying behavior. The proposed regression model thus becomes: $\mathrm{Y}=1.255+0.694 \mathrm{X} 1+\varepsilon$

\subsection{Discussion of Findings}

Research objective one was to ascertain the effect of rebates on consumer buying behavior of Maggi NAIJA POT. The result of hypothesis one confirms that there is a positive effect of rebates on consumer buying behavior in Bwari Area Council, Abuja. The findings revealed most of the consumers enjoy the rebates which influence their decision before, during and after the purchase. The research findings gave answer to the research question and the alternative hypothesis one which stated that there is a significant effect of rebates on consumer buying behavior of Nestle Maggi NAIJA POT was accepted. These finding 
collaborates with the findings of the study by Zhang (2016) rebates have a market effect and are beneficial to the manufacturer and to consumers.

Research objective two was to ascertain the effect of free trail on consumer buying behavior of Maggi NAIJA POT among Nigerian households. The result of hypothesis two confirms that there is a positive effect of free trail on consumer buying behavior in Bwari Area Council, Abuja. This implies that free samples stimulate the trial of a new product during the introduction stage of the product. Providing free samples is a technique used to introduce new products to the marketplace. Samples give the consumer a chance to see how well they like a product or try something they otherwise would not normally buy. In comparison to other studies, the findings are in line with the findings of Ben Amor and Guilbert (2009) who found that after a period of free samples, the samples significantly increase the immediate sale of the product.

Research objective three was to ascertain the effect of free gifts on consumer buying behavior of Nestle Maggi NAIJA POT. The result of hypothesis three confirms that there is a positive effect of free gifts on consumer buying behavior in Bwari Area Council, Abuja. This result demonstrates that free gifts are an effective sales promotional tool. Free gifts entice consumers to make a purchase by including a bonus along with the product. The gift may be included in the outer part of the product packaging to serve as a visual attraction. It may also take the form of a prize inside the package. The finding is supported by other studies such as Zhu, Chang and Chang (2015) who found that Perceived usefulness, perceived quality, perceived cost, and perceived ingenuity are antecedents of happiness toward a free gift with purchase.

\section{Conclusion}

Confirming with the findings of this study, it suggests that sales promotion through rebates, free trial and free gifts is one significant tool marketing companies should give attention to in order to influence their consumers' buying behaviour. The findings of this research support the findings of previous researchers. Further it can be concluded that effective sales promotion is a tool to influence consumer behaviour. This study elicits the key determinants of sales promotion which can be nurtured by the management of companies to better influence consumer purchase behavior. Hence this study widens the scope of identifying measures that will enhance organization performance like rebates, free trial and free gifts.

Based on the findings, the study recommends the following:

1. Since most of the consumers enjoy the rebates which influence their decision before, during and after the purchase, Nestle Nigeria Plc should continue to adopt that in promoting their new products in Nigeria.

2. Providing free samples is a good technique to use in introducing new products to the Nigerian marketplace. Samples give the consumer a chance to see how well they like a product or try something they otherwise would not normally buy.

3. Free gift should be included in the outer part of the product packaging to serve as a visual attraction to Nigerian consumers. It may also take the form of the commonly used terminology BOGOF' (Buy one get one free) 


\section{References}

Ahungwa, A.I (2018) Effect of Sales Promotion on Consumer Buying Behavior: A Case Study of Nestle Nigeria Plc' BSc Project, Department of Business Administration, Veritas University, Abuja, Nigeria

Ben Amor, I., \& Guilbert, F. (2009). Influences on free samples usage within the luxury Cosmetic Market. An International Journal of Direct Marketing:3(1), 67-82

Daramola, G.C., Okafor, L.I. \& Bello,M.A (2014).Sales Promotion on Consumer Buying Behaviour. International Journal of Business and Marketing Management, 2(1):8-13

Evans, J. \& Berman,B. (1997). Marketing. New Jersey: Prentice Hall International

Gilbert, D.C.\& Jackaria, N. (2002). The Efficacy of Sales Promotions in U.K. Retail Stores: A Consumer View. International Journal of Retail and Distribution Management, 30:315- 332

Jobber, D. \& Lancaster, G.(2006). Selling and Sales Management, (7th edn), Harlow: Pearson Education

Joseph C. (2018) Consumer sales promotion techniques'. Retrieved from http://smallbusiness.chron.com/consumer-sales-promotion-techniques-1035.html

Kotler, P.J. \& Armstrong, G.M. (2010). Principles of Marketing, Global Ed. New York: Pearson.

Kwok, S. \& Uncles, M. (2005). Sales Promotion Effectiveness: The Impact of Consumer Differences at an Ethnic-Group Level. Journal of Product \& Brand Management, 14:170-186.

Lu, Q \& Moorthy, S (2007). “Coupons Versus Rebates.” Marketing Science, 26 (1).

Mendez M. (2012) Sales promotions effects on brand loyalty. Retrieved from NHU works, H. Wayne Huizenga College of Business and Entrepreneurship

Mahmud, I.N., Mohammad, S.A. \& Sultan, F. (2014). The Impact of Promotional Mix Elements on Consumers Buying Decisions. International Business and Management, 8: 143-151.

Neslin, S.A. (2002). Sales Promotion. Cambridge, MA: Marketing Science Institute (MSI).

Orji MG (2017) Impact of Personality Factors on Consumer Buying Behavior of Textile Materials in South Eastern Nigeria (PhD Thesis) Department of Business Administration, Ahmadu Bello University, Zaria, Nigeria,

Orji, M.G, Sabo, B., Abubakar, M.Y, Usman, A.D (2017) 'Impact of Personality Factors on Consumer Buying Behaviour Towards Textile Materials in South Eastern Nigeria' International Journal of Business and Economics Research. USA, Vol. 6, No. 1,pp.718

Orji, Akhaine, Ezinmuo \& Boman (2019) Effect of promotional activities on brand loyalty of detergents among Nigerian university students: A study of veritas University Abuja' International Journal of Research in Marketing Management and Sale 1(1): 30-39

Osuala EC (1998). Fundamentals of Nigeria Marketing. Onitsha: Cape Publishers International Ltd. P. 167.

Romdony, J. Juju. U, Jusuf, E., Rosmadi . M.L.N (2018) The Factors That Affect Customer Value and Its Impact on the Customer Loyalty' Budapest International Research and Critics Institute-Journal (BIRCI-Journal) Volume I, No 4, PP1-7 
Romdony, J \& Rosmadi, M.L.N(2019) Factors Affecting Customer Loyalty in Products' Budapest International Research and Critics Institute-Journal (BIRCI-Journal) Volume 2, No 1PP1-7

Zhang, J. (2016). The benefits of consumer rebates: A strategy for gray market deterrence. European Journal of Operational Research, 251(2), 509-521

Zhu, D. H., Chang, Y. P., \& Chang, A. (2015). Effects of free gifts with purchase on online purchase satisfaction: The moderating role of uncertainty. Internet Research, 25(5), 690-706.

www.pmnewsnigeria.com/2017/11/07; nestle-launches-new cooking cubes 